\title{
Pregnancy outcome in women with sickle cell disease/trait in a tertiary care hospital Nagpur, Maharashtra India: a descriptive cross sectional study
}

\author{
$\operatorname{Varsha~Kose~}^{1 *}$, Saurabh Kose ${ }^{2}$
}

\begin{abstract}
${ }^{1}$ Department of Obstetrics and Gynecology, N. K. P. Salve Institute of Medical Sciences and Research Centre, Digdoh Hills, Hingna Road, Nagpur, Maharashtra, India

${ }^{2}$ Intern, N.K.P. Salve Institute of Medical Sciences and Research Centre, Nagpur, Maharashtra, India
\end{abstract}

Received: 01 July 2019

Accepted: 07 September 2019

\section{*Correspondence:}

Dr. Varsha Kose,

E-mail: varshadkose@rediffmail.com

Copyright: ( $)$ the author(s), publisher and licensee Medip Academy. This is an open-access article distributed under the terms of the Creative Commons Attribution Non-Commercial License, which permits unrestricted non-commercial use, distribution, and reproduction in any medium, provided the original work is properly cited.

\begin{abstract}
Background: Pregnancy in sickle cell women has numerous obstetrical, nonobstetrical and fetal complications. Our objective was to study the pregnancy outcome in women with sickle cell disease/trait.

Methods: A descriptive cross sectional study in 2 years study period was conducted. 57 women with sickle cell disease/trait were identified. They were attending the antenatal clinic and were admitted in obstetric ward and followed till 7 days after delivery.

Results: Out of total 57 women 49 women $(85.96 \%)$ were sickle cell trait (AS pattern) and 8 women $(14.03 \%)$ were sickle cell disease (SS pattern). In women with sickle cell trait Pregnancy induced hypertension was the most common complication. Anaemia and hypothyroidism was the common associated medical problem. 5 babies need NICU admission, 6 babies PBU admission and 33 babies given to mother side just after birth. In women with sickle cell disease severe anaemia, preeclampsia, oligohydramnios and intrauterine growth restriction, lower segment caesarean section for preterm baby was the most common complication. 1 baby required NICU admission, 5 babies require PBU admission and only 2 babies given to mother just after delivery. There were no maternal mortality and neonatal mortality.

Conclusions: Maternal morbidity and neonatal morbidity is more in sickle cell disease women. They require early diagnosis, premarital and preconceptional counselling, good multidisciplinary obstetrics and neonatal care and early referral to higher centre.
\end{abstract}

Keywords: Maternal morbidity, Perinatal outcome, Sickle cell disease

\section{INTRODUCTION}

Haemoglobinopathies are a group of disorders which affect the haemoglobin molecule in its structure, function or production. Sickle cell disease (SCD) includes a group of single gene autosomal recessive disorders caused by sickle gene which affects the haemoglobin structure. A substitution of valine for glutamine in position 6 in the beta-globin chains of the hemoglobin molecule results in the production of the sickle cell hemoglobin ( $\mathrm{HbSS})$ also called sickle cell anaemia (SS pattern). Sickle cell trait (AS pattern) is heterozygous for the SCD gene mutation and has only one beta chain affected.

Globally India accounts for $14.5 \%$ of the total newborns with SCD. The first description of sickle cell 
haemoglobin in India was by Lehman and Cutbsh in 1952 in the tribal populations in the Nilgiri hills in South India. Many population groups have been screened in India and sickle cell gene has been shown to be prevalent among three socioeconomically disadvantaged ethnic groups-the scheduled caste, scheduled tribes and other backward classes.

Pregnancy in sickle cell women has numerous obstetrical, nonobstetrical and fetal complications. SCD has been proposed to be a chronic inflammatory state. Endothelial damage secondary to sickled red blood cells and the subsequent release of pro-inflammatory cytokines may contribute to micro vascular damage. Normal vascular endothelial and inflammatory adaptation in pregnancy may lead to exacerbation of these pathophysiologic changes with manifestation of resulting maternal complications such as preeclampsia and fetal growth restriction.

The main maternal complications of pregnancies complicated by sickle cell disease are anemia, infection, vasoocclusive crisis and preeclampsia.

Fetal problems affecting perinatal outcome are intrauterine growth restriction, premature birth, abnormal fetal heart rate, and intrauterine fetal death. Complications of sickle cell disease precipitate preterm labour and increase the risk of caesarean section to improve the pregnancy outcome. High maternal and fetal morbidity and mortality seen in pregnant mother with sickle cell disease. ${ }^{1}$

Sickle cell trait is also potentially dangerous in the presence of certain disease states and in healthy persons under certain circumstances which lead to anoxia, dehydration or physical stress. $^{2}$

This study was undertaken to assess the pregnancy outcome in women with sickle disease and sickle cell trait at our centre who provides services to sickle cell prone ethnic groups. So we can make treatment plan for better pregnancy outcome.

\section{METHODS}

A descriptive observational study was conducted in the Department of obstetrics and gynecology in a tertiary care hospital Nagpur (M.S) India after institutional ethics approval. Pregnant women attending the Department for antenatal follow up and delivery were checked for sickling early and delayed test. If they found positive they were further advised for $\mathrm{Hb}$ electrophoresis test. Those with diagnosed sickle cell disease/sickle cell trait were identified and included in the study. The study period was 2 years from July 2016.

Only those women who delivered or aborted at our institute were included. Patients were included irrespective of gravida, parity and registration status. It is to be emphasized that haemoglobin electrophoresis was not advised to all women for the purpose of this study.

Patients who are willing to participate in the study, written and informed consent were taken. At the time of admission for delivery, physical examination and relevant investigations were all documented in case record form.

\section{The parameters which were studied are as follows}

Details regarding whether antenatal genetic counseling and invasive procedure to diagnose problems in the fetus was done were noted. All complications during antenatal, intranatal and postnatal period, Requirement of blood and its components in the antenatal, intranatal and postnatal period were noted. Obstetric outcome such as duration of pregnancy, mode of delivery details regarding any abnormality during pregnancy and abnormal course in the labour were noted.

Neonatal outcomes such as birth weight, Neonatal intensive care unit admission/premature baby unit admission were noted. All collected data were kept confidential and entered in excel sheet. Being an observational study simple statistical calculation like percentages were used.

\section{Operational definitions}

- Anaemia among pregnant women defined as haemoglobin level less than $11 \mathrm{gm} / \mathrm{dl}$. Severe anaemia defined as $\mathrm{Hb}$ level less than $7 \mathrm{gm} / \mathrm{dl}$

- Preterm pregnancy - birth before 37 weeks of gestation

- $\quad$ Low birth weight baby - birth weight less than $2.5 \mathrm{~kg}$

- Very low birth weight - birth wt less than $1.5 \mathrm{~kg}$.

Antepartum haemorrhage - Bleeding from or into vagina after 28 weeks of pregnancy up to $2^{\text {nd }}$ stage of labour.

Gravida - Number of times patient becomes pregnant irrespective of their outcome.

Parity - Number of times patient delivers after 28wks of gestation.

Preeclamsia - Condition in which high blood pressure and protein in urine develop after $20^{\text {th }}$ week of pregnancy. ${ }^{3-5}$

\section{RESULTS}

Total 57 pregnant women with sickle cell trait (AS pattern) and sickle cell disease (SS pattern) were identified and included in the study. During this 2 years study period there were 4,340 deliveries and 297 abortions in the hospital. Out of total 57 women $70 \%$ were scheduled caste, $20 \%$ were Scheduled tribe and other backward community, 5\% were Muslims and 5\% belonged to general category. Maximum women $84.21 \%$ 
were in the age group between $20-30$ years. $15.78 \%$ were in the age group between 31-40years. 23 women $(40.35 \%)$ were primigravida. 34 women $(59.64 \%)$ were multigravida. Out of total 57 women 49 women $(85.96 \%)$ were sickle cell trait (AS pattern) and 8 women $(14.03 \%)$ were sickle cell disease (SS pattern) (Table 1).

Table 1: Distribution of sickle cell disease and trait in women.

\begin{tabular}{|lll|}
\hline Genotype & Number & Percentage \\
\hline AS Pattern & 49 & 85.96 \\
\hline SS Pattern & 8 & 14.03 \\
\hline Total & $\mathbf{5 7}$ & $\mathbf{1 0 0}$ \\
\hline
\end{tabular}

45 women $(78.94 \%)$ were sickle cell trait (AS pattern) with husband normal Haemoglobin (AA pattern). 4 women $(7.01 \%)$ had AS pattern with husband AS pattern. 6 women $(10.52 \%)$ had SS pattern with husband AA pattern. 2 women $(3.5 \%)$ had SS pattern with husband also had SS pattern (Table 2).
Table 2: Distribution of sickle cell disease and trait in women and their partner.

\begin{tabular}{|llll|}
\hline $\begin{array}{l}\text { Women } \\
\text { genotype }\end{array}$ & $\begin{array}{l}\text { Husband } \\
\text { genotype }\end{array}$ & Number & Percentage \\
\hline AS & AA & 45 & 78.94 \\
\hline AS & AS & 4 & 7.01 \\
\hline SS & AA & 6 & 10.52 \\
\hline SS & SS & 2 & 3.50 \\
\hline
\end{tabular}

In our study out of total 49 women with sickle cell trait 3 women $(6.12 \%)$ had $\mathrm{Hb}$ less than $7 \mathrm{gm} / \mathrm{dl}, 20$ women (40.81\%) had 7-10gm/dl, 20 women $(40.81 \%)$ had $\mathrm{Hb}$ $10-11 \mathrm{gm} / \mathrm{dl}, 6$ women $(12.24 \%)$ had $\mathrm{Hb}$ more than $11 \mathrm{gm} / \mathrm{dl}$. Out of total 8 women, 3 women $(37.5 \%)$ had $\mathrm{Hb}$ less than $7 \mathrm{gm} / \mathrm{dl}$, 5 women $(62.5 \%)$ had $\mathrm{Hb} 7-10$ $\mathrm{gm} / \mathrm{dl}$. No women with SS disease had Hb more than $10 \mathrm{gm} / \mathrm{dl}$. 7 women $(12.28 \%)$ required blood transfusion 3 women were AS pattern and 4 women were SS pattern (Table 3).

Table 3: Haemoglobin levels.

\begin{tabular}{|llll|}
\hline Hb percentage & AS Pattern 49 women $(\mathbf{8 5 . 9 6 \% )}$ & SS Pattern 8 women $(\mathbf{1 4 . 0 3 \% )})$ & Total (57) \\
\hline$>11$ & $6(12.24 \%)$ & 0 & $6(10.52 \%)$ \\
\hline $10-11$ & $20(40.81 \%)$ & 0 & $20(35.08 \%)$ \\
\hline $7-10$ & $20(40.81 \%)$ & $5(62.5 \%)$ & $25(43.85 \%)$ \\
\hline$<7$ & $3(6.12 \%)$ & $3(37.5 \%)$ & $6(10.52 \%)$ \\
\hline
\end{tabular}

Table 4: Associated medical high-risk factors.

\begin{tabular}{|lllll|}
\hline Medical high-risk factor & AS pattern & SS pattern & Total & Percentage \\
\hline Severe anaemia & 4 & 2 & 6 & 10.52 \\
\hline Hypothyroidism & 5 & 1 & 6 & 10.52 \\
\hline Urinary tract inf. with fever & 0 & 2 & 2 & 3.50 \\
\hline Diabetes & 1 & 1 & 2 & 3.50 \\
\hline Hyperthyroidism & 1 & 0 & 1 & 1.75 \\
\hline Urinary tract infection & 1 & 1 & 2 & 3.50 \\
\hline Chronic hypertension & 1 & 0 & 1 & 1.75 \\
\hline NYHA heart disease gr & 0 & 1 & 1 & 1.75 \\
\hline HbSAg positive & 1 & 0 & 1 & 1.75 \\
\hline VDRL positive & 1 & 0 & 1 & 1.75 \\
\hline Jaundice & 0 & 1 & 1 & 1.75 \\
\hline Fever & 1 & 2 & 3 & 5.26 \\
\hline Glaucoma & 1 & 0 & 1 & 1.75 \\
\hline
\end{tabular}

Out of total 49 women $(85.96 \%) 5$ women $(10.20 \%)$ had hypothyroidism, 4 women $(8.16 \%)$ had severe anaemia and 1 woman (2.04\%) each had diabetes, hyperthyroidism, urinary tract infection, chronic hypertension, HbSAg positive, VDRL positive, fever and glaucoma.
Out of total 8 women $(14.03 \%), 2$ women $(25 \%)$ had severe anaemia, 2 women $(25 \%)$ had urinary tract infection with fever, 2 women $(25 \%)$ had fever. 1 woman $(12.5 \%)$ each had hypothyroidism, diabetes, urinary tract infection without fever, NYHA heart disease grade 4 , and jaundice. 
2 women required medical intensive care unit (MICU) admission. One woman with AS pattern developed breathlessness and chest pain on day 2 of caesarean section. Second woman with SS pattern developed fever with respiratory tract infection with icterus. Both improved with medical management. There was no maternal mortality. Two women both with SS pattern were admitted to MICU directly from casualty in sickle cell crisis. They had 29th and 30th week pregnancy and discharged from medicine department only. They lost to follow up so not included in the study (Table 4).

Table 5: Associated obstetrical problems.

\begin{tabular}{|lllll|}
\hline Obstetrical problems & AS pattern & SS pattern & Total & Percentage \\
\hline Abruptio placenta & 0 & 1 & 1 & 1.75 \\
\hline Postpartum haemorrhage & 1 & 0 & 1 & 1.75 \\
\hline IUGR with oligohydramnios & 2 & 3 & 5 & 8.77 \\
\hline Twins & 1 & 1 & 2 & 3.50 \\
\hline Breech with IUGR & 1 & 0 & 1 & 1.75 \\
\hline Previous caesarean & 4 & 2 & 6 & 10.52 \\
\hline Pregnancy induced hypertension & 3 & 2 & 5 & 8.77 \\
\hline Gestational diabetes & 1 & 1 & 2 & 3.50 \\
\hline Incomplete abortion & 2 & 0 & 2 & 3.50 \\
\hline Intrauterine death & 1 & 1 & 2 & 3.50 \\
\hline Ectopic pregnancy & 1 & 0 & 1 & 1.75 \\
\hline Missed abortion & 0 & 1 & 1 & 1.75 \\
\hline Caesarean section wound gaping - resuturing & 1 & 0 & 1 & 1.75 \\
\hline
\end{tabular}

Table 6: Distribution of pregnancy outcome.

\begin{tabular}{|lllll|}
\hline Mode of pregnancy termination & AS pattern & SS pattern & Total number & Percentage \\
\hline Full term normal vaginal delivery & 18 & 2 & 20 & 35.08 \\
\hline Preterm vaginal delivery & 8 & 0 & 8 & 14.03 \\
\hline Lower segment caesarean section & 23 & 17 & 6 & 40.35 \\
\hline Intrauterine death & 2 & 1 & 1 & 3.50 \\
\hline Suction and evacuation & 3 & 2 & 1 & 5.26 \\
\hline Ectopic pregnancy & 1 & 0 & 1 & 1.75 \\
\hline
\end{tabular}

Table 7: Birth weight.

\begin{tabular}{|llll|l|}
\hline Birth weight in $\mathrm{kg}$ & AS pattern (49 women) & SS pattern (8 women) & Total (57 women) & Percentage \\
\hline $1-2$ & 5 & 5 & 10 & 17.54 \\
\hline $2-2.5$ & 12 & 3 & 15 & 26.31 \\
\hline More than 2.5 & 28 & 0 & 28 & 49.12 \\
\hline
\end{tabular}

Table 8: Neonatal outcome.

\begin{tabular}{|lllll|}
\hline Neonatal outcome & AS pattern (49 women) & SS pattern (8 women) & Total (57 women) & Percentage \\
\hline NICU admission & 6 & 1 & 7 & 13.20 \\
\hline PBU admission & 6 & 5 & 11 & 20.75 \\
\hline Mother side & 33 & 2 & 35 & 66.03 \\
\hline
\end{tabular}

Out of total 49 women $(85.96 \%) 4$ women $(8.16 \%)$ had previous caesarean section, 3 women $(6.12 \%)$ had pregnancy induced hypertension, 2 women $(4.08 \%)$ had intrauterine growth restriction and oligohydramnios, 2 women $(4.08 \%)$ had incomplete abortion. 1 woman $(2.04 \%)$ each had postpartum haemorrhage, twin pregnancy, breech with IUGR, gestational diabetes, intrauterine dead baby, ectopic pregnancy, and one had resuturing surgery for post caesarean section wound gaping.

Out of 8 women (14.03\%) 3 women (37.5\%) had intrauterine growth restriction with oligohydramnios, 2 women $(25 \%)$ had previous caesarean section, 2 women $(25 \%)$ had pregnancy induced hypertension, 1 woman $(12.5 \%)$ each had abruption placenta (antepartum 
haemorrhage), twins, gestational diabetes, missed abortion and intrauterine death baby (Table 5).

Out of 49 women with AS pattern 18 women $(36.73 \%)$ had full term normal vaginal delivery, 8 women $(16.32 \%)$ had preterm vaginal delivery, 17 women $(34.69 \%)$ had lower segment caesarean section, 1 intrauterine dead baby ( 28 weeks gestation), 2 (4.08\%) suction evacuation for incomplete abortion, $1(2.04 \%)$ ectopic pregnancy. Exploratory laparotomy followed by salpingectomy was done for ruptured ectopic pregnancy. Out of 8 women with SS pattern 2 women $(25 \%)$ had fullterm normal vaginal delivery, 6 women $(75 \%)$ had lower segment caesarean section, 1 woman $(7.12 \%)$ had suction evacuation for missed abortion, 1 woman (12.5\%) had intrauterine dead baby ( 29 weeks gestation), who had severe anaemia, severe preeclampsia, intrauterine growth retardation and severe oligohydramnios.

Out of total 57 women, only 2 women received preconceptional counselling and genetic diagnosis. In First woman where first child was SS pattern, both parents were AS pattern. Second in whom both patient and husband were SS pattern. Women was 40 years old, she had taken infertility treatment 3 years back and stopped. She conceived spontaneously had twin pregnancy with hypothyroidism, severe preeclampsia, gestational diabetes and severe anaemia. She also had severe oligohydramnios with intrauterine growth restricted babies. In spite of high risk case and both parent SS pattern they opted to continue pregnancy. Elective caesarean section was done at 36 week gestation. She received 2 packed cell transfusions. Both babies with low birth weight kept in premature baby unit. Unfortunately with good intranatal and postnatal multidisciplinary care mother's postoperative period was uneventful except lactation failure (Table 6).

Out of total 53 babies with sickle cell trait 5 babies (were between $1-2 \mathrm{~kg}, 12$ babies were between $2-2.5 \mathrm{~kg}, 28$ babies were more than $2.5 \mathrm{~kg}$. Sickle cell disease women's 5 babies had birth weight $1-2 \mathrm{~kg}, 3$ babies had weight between $2-2.5 \mathrm{~kg}$ and no baby had wt more than $2.5 \mathrm{~kg}$ (Table 7).

Out of total 53 babies, in sickle cell trait women 6 babies required neonatal intensive care unit admission, 6 babies required premature baby unit admission, 33 babies were given to mother side after delivery. In sickle cell disease women 1 baby admitted to neonatal intensive care unit, 5 babies were admitted to premature baby unit, and only 2 babies given to mother side after delivery. 4 babies were from twin pregnancy one from AS mother and one from SS mother. All 4 babies were admitted to premature baby unit (Table 8).

\section{DISCUSSION}

Vidarbha area in Maharashtra is one of the high prevalence parts for sickling positive cases. The disease is commonly seen in Scheduled caste and Scheduled tribe population. With more awareness about the disease and better treatment options and facilities more females are reaching the child bearing age. This has lead to an increase in the number of pregnant women reaching for institutional delivery.

In our study we have done sickling early and late test in each antenatal woman. If sickling test was positive than $\mathrm{Hb}$ electrophoresis was advised to them to know the genotype, sickle cell disease (SS pattern) or sickle cell trait (AS pattern). We also included those women who had documented $\mathrm{Hb}$ electrophoresis report from outside. In 2 years study period we identified total 57 pregnant women with sickle cell disease and trait. There were 4,340 deliveries in the hospital. It gives a rate of $1.31 \%$. Out of total 57 women, 49 women $(85.96 \%)$ were sickle cell trait and 8 women (14.03\%) were sickle cell disease.

In the present study out of total 57 women $70 \%$ were Scheduled caste, 20\% Scheduled tribe and OBC, 5\% were Muslims and 5\% were belonged to general category. In a study Sonwane et al, study group consisted of 118 pregnant women, 25 women $(21.18 \%)$ were sickle cell disease and 93 women $(78.81 \%)$ were sickle cell trait. $^{2}$

In our study out of total 49 women with sickle cell trait only 3 women $(6.12 \%)$ had $\mathrm{Hb}$ less than $7 \mathrm{gm} / \mathrm{dl}, 20$ women $(40.81 \%)$ had $7-10 \mathrm{gm} / \mathrm{dl}, 20$ women $(40.81 \%)$ had $\mathrm{Hb} 10-11 \mathrm{gm} / \mathrm{dl}$, and 6 women $(12.24 \%)$ had Hb more than $11 \mathrm{gm} / \mathrm{dl}$. Out of total 8 women, 3 women $(37.5 \%)$ had $\mathrm{Hb}$ less than $7 \mathrm{gm} / \mathrm{dl}$, 5 women $(62.5 \%)$ had $\mathrm{Hb} 7-$ $10 \mathrm{gm} / \mathrm{dl}$ and no women with SS disease had $\mathrm{Hb}$ more than $10 \mathrm{gm} / \mathrm{dl}$. 7 women $(12.28 \%)$ required blood transfusion 3 women $(6.12 \%)$ were AS pattern and 4 women $(50 \%)$ were SS pattern. In a study with Desai et al, only $8.4 \%$ require 3 or more blood transfusion.

In the study of Sonwane et al, out of total sickle cell trait women $22.58 \%$ women had $\mathrm{Hb}$ less than $8 \mathrm{gm} / \mathrm{dl}, 72.04 \%$ women had 8-10 gm/dl, and $5.37 \%$ had $\mathrm{Hb}$ more than $10 \mathrm{gm} / \mathrm{dl}$. In sickle cell disease women $56 \%$ women had had $\mathrm{Hb}$ less than $8 \mathrm{gm} / \mathrm{dl}$, $44 \%$ women had $\mathrm{Hb} 8-10 \mathrm{gm} / \mathrm{dl}$. No women had $\mathrm{Hb}$ more than $10 \mathrm{gm} / \mathrm{dl}$ as in our study. In a study by Couth SD et al, $100 \%$ moderate to severe anaemia in HbSS women and only $46.8 \%$ women with AS pattern were anaemic.

In the present study women with AS pattern (49 women) $18(36.73 \%)$ had full term normal vaginal delivery. 8 women $(16.32 \%)$ had preterm delivery, $34.69 \%$ had lower segment caesarean section, 1 (2.04\%) had intrauterine death, $2(4.08 \%)$ had suction and evacuation and $1(2.04 \%)$ had ectopic pregnancy. In women with SS pattern (8 women), 2 (25\%) had full term normal vaginal delivery, $6(75 \%)$ had lower segment caesarean section, 1 $(12.5 \%)$ had intrauterine death baby, 1 (12.5\%) had suction and evacuation, no women had preterm vaginal delivery. In a study of Couth SD et al women with sickle 
cell haemoglobinopathy have been found to have higher risk for preterm delivery. According to Desai $G$ et al and Ugobama et al the incidence of preterm birth was as high as $44-45 \%$. According to Couth SD et al preterm delivery was $18.06 \%$ which was consistent with two fold increased risk in Sickle cell disease women. Caesarean section also more as in our study, either due to maternal or fetal complications.

In our study only two women with sickle cell disease came with sickle cell crisis and admitted to intensive care unit. They had 28 and 29 weeks pregnancy respectively, and discharged from medicine Department only and lost to follow up. Pinto $\mathrm{S}$ et al had reported vasoocclusive crisis in $61.7 \%$ of women with sickle cell disease and acute chest syndrome as high as $29.4 \%$. In Couth SD et al $18.05 \%$ of vasoocclusive crisis and $5.56 \%$ of acute chest syndrome were observed.

In this study pregnancy induced hypertension was the main complication in sickle cell trait women. Preterm caesarean delivery was the main complication in sickle cell disease. These observations are similar to Sonwane et al where preterm deliveries in SS group $(72 \%)$ were compared to AS group (30.10\%).

In our study in women with sickle cell trait 5 babies were between $1-2 \mathrm{~kg}$ (very low birth weight), 12 babies were between $2-2.5 \mathrm{~kg}$ (low birth weight) and 28 babies were more than $2.5 \mathrm{~kg}$. In Sickle cell disease women 5 babies had birth weight $1-2 \mathrm{~kg}, 3$ babies had wt between $2-2.5 \mathrm{~kg}$ and no babies had weight more than $2.5 \mathrm{~kg}$.

In the present study out of total 53 babies, 45 babies were from in sickle cell trait mother. Out of these 45 babies 6 babies $(13.33 \%)$ required neonatal intensive care unit admission, 6 babies $(13.33 \%)$ required premature baby unit admission, 33 (73.33\%) babies were given to mother side after delivery. 8 babies were from sickle cell disease mother. Out of these 8 babies 1 baby $(12.5 \%)$ admitted to neonatal intensive care unit, 5 babies $(62.5 \%)$ were admitted to premature baby unit, and only 2 babies (25\%) given to mother after delivery. 4 babies were from twin pregnancy one from AS mother and one from SS mother. All 4 babies were admitted to premature baby unit. Sickle cell disease in pregnancy women has been associated with low birth weight and was observed in about $50 \%$ pregnancy by Ugboma et al. In a study by Smith et al $56.94 \%$ babies less than $2.5 \mathrm{~kg}$ at birth and $14.49 \%$ babies with low apgar score.

In our study there were no maternal mortality and neonatal mortality within 7 days after delivery. Most of the babies especially in mother with sickle cell disease require premature baby unit admission and neonatal intensive care unit admission. Factors responsible for this may be lower gestational age at delivery, maternal anaemia, preeclampsia and intrauterine growth restriction.
Out of total 57 women only two women underwent preconceptional counseling. First woman was AS pattern with husband AS pattern. They underwent chorion villous biopsy as they had previous baby with SS pattern, delivered by caesarean section. Chorion villous sampling is a safe procedure for prenatal diagnosis of haemoglobinopathies. Asnafi et al have described a large series of patients undergoing CVS and confirmed the same. In a study by Anahita et al, 7 patients underwent CVS and there were no procedure related complication and pregnancy continued successfully. ${ }^{6,7}$ Second women in our study had SS pattern with husband also SS pattern. They received preconceptional counseling but opted to continue pregnancy. But these women had severe preeclampsia, gestational diabetes with hypothyroidism and severe anaemia. Most of the women were unaware of preconceptional counseling. Most of the women detected sickling positive first time during antenatal investigations. They were asymptomatic. Most of the women especially AS pattern mother had pregnancy without any complications. ${ }^{8,9}$

\section{CONCLUSION}

This study has identified an increased morbidity in pregnancy in women with Sickle cell disease and few in sickle cell trait. This is due to hypertensive disorder and aggravation of anaemia with intrauterine growth restriction and preterm delivery. Perinatal outcome was also adverse in sickle cell disease women. The outcome in sickle cell trait pregnant women is not a major concern. As most of the study population were identified to belong to the scheduled caste, scheduled tribe and other backward community, active screening programme need to be undertaken in the public health sector to identify women with sickle cell disease and trait. Premarital counselling can be offered to them. Measures should be taken to improve preconceptional counselling about the disease, better antenatal care, prompt identification and treatment of complications and referral to tertiary care centres.

\section{ACKNOWLEDGMENTS}

Authors would like to thank to the constant encouragement and support by Dr. Sulabha Joshi Professor and HOD Department of Obstetrics and Gynaecology, NKP Salve Institute of Medical Sciences, Nagpur, Maharashtra, India.

\section{Funding: No funding sources \\ Conflict of interest: None declared}

Ethical approval: The study was approved by the Institutional Ethics Committee

\section{REFERENCES}

1. D'Couth S, Kalam S. Fetomaternal outcome in sickle cell hemoglobinopathy in a tertiary care centre of 
north Kerala, India. Int J Repro Contra Obstet Gynecol. 2017;6(12):5299-305.

2. Sonwane A, Zodpey S. Pregnancy outcome in women with sickle cell disease/trait. The Journal of Obstetrics and Gynecology of India. 2005;55(5):4158.

3. Desai G, Anand A. Sickle cell disease and pregnancy outcomes: a study of the community - based hospital in a tribal block of Gujarat, India. J Health Populat Nutrit. 2017;3(36):1-13.

4. Muganyizi P, Kdanto H. Sickle cell disease in pregnancy: Trend and pregnancy outcomes at a tertiary Hospital in Tanzania. PLOS One. 2013:1-7.

5. Wilson NO, Ceesay FK. Pregnancy outcome among patients. Am J Trop Med Hyg. 2012;86(6):936-42.

6. Elenga N, Adeline A. Pregnancy in sickle cell disease is a very high risk situation: an observational study. Obstet Gynaecol Int J. 2016:1-5.
7. Mulla-Ali DH, Kuo KHM. The relationship between pregnancy, sickle cell disease specific complication and maternal and fetal outcome in sickle cell disease. Blood. 2011;118:1-3.

8. Kahansim ML, Ocheke AN. Pregnancy outcome among patients with sickle cell disease in Jos North central Nigeria, Jos J Med. 2014;8(3):9-13.

9. Anhita C, Madhva P. Outcome of pregnancy with haemoglobinopathy in a tertiary care centre. J Obstet Gynaecol India. 2018;68(5):394-9.

Cite this article as: Kose V, Kose S. Pregnancy outcome in women with sickle cell disease/trait in a tertiary care hospital Nagpur, Maharashtra India: a descriptive cross sectional study. Int J Reprod Contracept Obstet Gynecol 2019;8:3943-9. 